\title{
Monitoring the Susceptibility of Two Leptinotarsa decemlineata (Say) Populations to Bacillus thuringiensis ssp. tenebrionis
}

\author{
G. GEGENWART ${ }^{1,2}$ and G.-A. LANGENBRUCH ${ }^{2}$ \\ ${ }^{1}$ Szent István University, Faculty of Horticulture Science, Department of Entomology, \\ H-1502 Budapest, P.O. Box 53, Hungary \\ ${ }^{2}$ Federal Biological Research Center for Agriculture and Forestry, Institute for Biological Control, \\ D-64287 Darmstadt, Heinrichstrasse 243, Germany
}

\begin{abstract}
Standardized laboratory bioassays were carried out at the Institute for Biological Control of the Federal Biological Research Center for Agriculture and Forestry to determine the susceptibility of two Colorado potato beetle (CPB) populations to Bacillus thuringiensis ssp. tenebrionis (B.t.t.). The beetles were collected from fields near Darmstadt/Hessen, and Michelfeld/Baden-Württemberg. The Michelfeld population, collected from an ecological farm, was sprayed since 1993, once or twice a year with NOVODOR FC, a formulation of B.t.t. The Darmstadt population was never sprayed with B.t.t. before. Our studies showed that the susceptibility of the larvae $\left(\mathrm{LD}_{50}\right.$ values) of the two populations did not differ each other significantly. Although resistance of CPB to B.t.t. under laboratory conditions has already been demonstrated, our presumption is that the resistance development of CPB on the field is probably much slower when the farmer is using crop rotation.
\end{abstract} susceptibility.

Keywords: Bacillus thuringiensis ssp. tenebrionis, Colorado potato beetle, population, resistance,

Bacillus thuringiensis ssp. tenebrionis (B.t.t.) was discovered in Darmstadt, Germany, in 1982 (Krieg et al., 1983, 1984). The $\delta$-endotoxin of the novel Bacillus thuringiensis strain (pathotype $\mathrm{C}$ ) is especially active against leaf beetles (Chrysomelidae), but ineffective against Lepidoptera, Diptera, or other insect orders. In the following years Herrnstadt et al. (1986) reported about another strain with coleopteran activity, Bacillus thuringiesis ssp. san diego, which was later found to be identical to B.t.t. (Krieg et al., 1987). The chrysomelid active character of B.t.t. has allowed scientists to start laboratory and field experiments with Colorado potato beetle (CPB).

The results of the field experiments in Germany showed that B.t.t. could play an important role in the future as a successful tool for the biological control of larvae of the CPB (e.g. Langenbruch et al., 1985; Langenbruch and Riethmüller, 1990; Langenbruch and Hommel, 1991; Langenbruch, 1992; Gürlich and Langenbruch, 1994). The scientific results of American researchers were similar. Ferro and Gelernter (1989), Zehnder and Gelernter (1989), Ferro and Lyon (1991) and Hough-Goldstein et al. (1991) reported about successful biological control with different formulations of B.t.t.

The $\delta$-endotoxin of B.t.t. is an environmentally sound alternative to broad spectrum synthetic insecticides to control CPB. Recently, products based on B.t.t. and licenced as a biological insecticide are available on the markets of most countries in Europe and 
North-America (NOVODOR FC). Biological insecticides are mainly used IPM growers, ecological farmers and ecological thinking hobby-gardeners. The Cry $3 \mathrm{~A} \delta$-endotoxin has already been genetically engineered into potatoes, too (Gasser and Fraley, 1989). These modificated potatoes producing $\delta$-endotoxin against the $\mathrm{CPB}$ are already available on the American market.

Whalon et al. (1993) first reported about resistance of CPB against B.t.t. under laboratory conditions. After 12 generations of B.t.t. selection, the selected CPB strain was 59 times more resistant than the unselected CPB strain, and 24-35 times more resistant than other susceptible, or insecticide-resistant strains. Rahardja and Whalon (1995) investigated the genetic inheritance of CPB resistance to B.t.t. $\delta$-endotoxin. They suggested that the resistance might be caused by more than one locus. The resistance was not stabile. When the selection pressure was removed, the resistance level of the selected colony decreased after five generations. Trisyono and Whalon (1997) reported about the fitness costs of resistance to B.t.t. In their experiments the resistant females produced $60 \%$ fewer eggs than susceptible ones.

Is the development of B.t.t. resistance to be expected in the field (e.g. on isolated farms using NOVODOR for a long time)? Must ecological farmers be afraid to loose an effective biological tool against CPB soon? Can the susceptibility of the CPB larvae towards B.t.t. be measured with standardised methods?

\section{Materials and Methods}

\section{Colony and bioassay}

At the end of May, 1999, CPBs were collected from two German farms. One of the farms (Michelfeld / Baden-Württemberg) produces agricultural products ecologically. Therefore, NOVODOR FC has been used once or twice a year, for a period over 5 years, to control CPB. The other farm, where imagines were collected, is found $10 \mathrm{~km}$ from Darmstadt / Hessen. B.t.t. was never sprayed here before. The two colonies, which were maintained in the greenhouse of the institute, allowed to carry out bioassays to determine the susceptibility of the $\mathrm{L}_{1}$ larvae towards B.t.t.

In laboratory bioassays, according to Riethmüller and Langenbruch (1989), $\mathrm{L}_{1}$ larvae $24 \mathrm{hrs}$ after hatching and holding on potato leaves tested to determine the $\mathrm{LD}_{50} .10$ small leaf discs $(\mathrm{d}=3 \mathrm{~mm})$, each bioassay contained five treatments, in three repetitions treated with 2 microliter distilled water, and with four ascending contrentrations of the product NOVODOR FC, which contains according to the German index of plant protection products $20 \mathrm{~g}$ B.t.t. $/ \mathrm{kg}$. Every assay was repeated three times. After 48 hours on the treated leaf discs, the larvae received untreated potato leaves until the end of the experiment. After six days the dose-mortality-effect was determined. The temperature during the experiment was $24 \pm 1{ }^{\circ} \mathrm{C}$, the photoperiod 16:8 LD. 


\section{Data analysis}

Data were analysed by probit regression (Finney, 1971); Abbott's (1925) formula was used to correct the mortality. Bioassays with more than $10 \%$ control mortality were not evaluated. With probit-regression the $\mathrm{LD}_{50}$ value with the $95 \%$ fiducial limits, and the slope of the regression line with the standard deviation, could be computed. Eight bioassays were carried out with the Darmstadt population, and seven bioassays with the Michelfeld population. On the one hand, the $\mathrm{LD}_{50}$ values of the populations could be compared with $t$-test, but this method does not take the $95 \%$ fiducial limits into consideration. On the other hand, there is a possibility by the probit-regression to compare two regression lines after computing a new common slope. With this method to determine an estimate of relative medium potency (and 95\% fiducial limits) the two populations are comparable (Daum and Killcreas, 1966).

Because of the asynchronous egg laying of the imagines in the different CPB strains it was not possible to carry out the bioassays parallel. Therefore, summarising the replications of the populations $(8 \times 3=24$ replications by the Darmstadt population, and $7 \times 3=21$ replications by the Michelfeld population) seems to be a right way. This method does not take the different larval body weight into consideration, but because of the large number of investigated larvae (about 1000/population) it is a sure method. The larval body weight could have influenced the $\mathrm{LD}_{50}$. Therefore, the larval body weight of both populations should previously be compared. Because all other circumstances of the bioassays were similar, summarizing of the replications is possible when no significant differences between the two groups are found.

\section{Results and Discussion}

Table 1 shows the larval body weight and the $\mathrm{LD}_{50}$ values computed with the probit regression analysis, the $95 \%$ fiducial limits of $\mathrm{LD}_{50}$ values, and the slope with the standard error for every bioassay.

As Table 2 shows using the t-test for statistical analysis, with respect to body weight, no significant difference was found between the populations $(t=1.149 ; \mathrm{df}=13$; $\mathrm{P}=0.271$ ). The fact that the larval body weight did not differ from each other can be easily explained. The larvae used for bioassays were held 24 hours after hatching on untreated potato leaves. All of them had the possibility to consume enough. The fact that the larval body weights are homogeneous in the two groups, allowed us concentrate all replicates.

By comparing the $\mathrm{LD}_{50}$ values with t-test the differences were also not significant $(\mathrm{t}=0.059 ; \mathrm{df}=13, \mathrm{P}=0.954)$. This test cannot take $95 \%$ fiducial limits into consideration, so, before rating this result, the other evaluation method (concentrating of all replicates) should be completed.

Table 3 contains the data of the probit regression after the concentration of all replicates. The average body weight of the Darmstadt population was $1.13 \mathrm{mg}$, the Michelfeld population $1.31 \mathrm{mg}$. The computed $\mathrm{LD}_{50}$ values hardly differred from each other: $2.38 \times 10^{-6} \mathrm{mg}$ B.t.t./larva of the Darmstadt population, and $2.12 \times 10^{-6} \mathrm{mg}$ B.t.t. of larva by the Michelfeld population. An interesting effect is that the Michelfeld population with the heavier larval body weight is somewhat more susceptible to B.t.t. than the Darmstadt population. 
Table 1

Body weight, $\mathrm{LD}_{50}$ value and spole for each bioassay of the tested populations

\begin{tabular}{ccccc}
\hline $\begin{array}{c}\text { Number of } \\
\text { bioassay }\end{array}$ & $\begin{array}{c}\text { Body weight } \\
(\mathrm{mg} / \text { larva })\end{array}$ & $\begin{array}{c}\mathrm{LD}_{50}(\mathrm{mg} \text { B.t.t.larva }) \\
\times 10^{-6}\end{array}$ & $\begin{array}{c}\mathrm{LD}_{50} \\
95 \% \text { fiducial limits }\end{array}$ & $\begin{array}{c}\text { Slope } \\
\pm \mathrm{SE}\end{array}$ \\
\hline Darmstadt & & & & \\
& 0.85 & 2.50 & $1.93-3.17$ & $3.48 \pm 0.68$ \\
& 0.93 & 2.87 & $2.04-4.56$ & $2.43 \pm 0.49$ \\
& 0.95 & 2.14 & $1.47-2.97$ & $2.13 \pm 0.48$ \\
& 0.97 & 1.92 & $1.41-2.46$ & $2.96 \pm 0.57$ \\
& 1.00 & 2.67 & $2.22-3.25$ & $3.89 \pm 0.60$ \\
& 1.16 & 2.14 & $1.70-2.67$ & $2.82 \pm 0.45$ \\
Michelfeld & 1.25 & 2.65 & $1.83-4.01$ & $3.11 \pm 0.70$ \\
& 1.93 & & $1.65-2.80$ & $2.49 \pm 0.45$ \\
& & & & \\
& 1.36 & 1.74 & $1.25-2.28$ & $2.13 \pm 0.40$ \\
& 0.85 & 2.69 & $2.08-3.49$ & $2.82 \pm 0.52$ \\
& 1.21 & 1.77 & $1.40-2.21$ & $2.98 \pm 0.49$ \\
& 1.25 & 1.09 & $0.70-1.44$ & $2.37 \pm 0.48$ \\
& 1.40 & 2.11 & $1.56-2.82$ & $2.11 \pm 0.40$ \\
& 1.50 & 2.05 & $1.43-2.92$ & $1.79 \pm 0.40$ \\
& 1.61 & 5.42 & $0.37-12.7$ & $1.73 \pm 0.44$ \\
\hline
\end{tabular}

Table 2

Mean of larval body weight and $\mathrm{LD}_{50}$ per population

\begin{tabular}{ccc}
\hline Population & $\begin{array}{c}\text { Body weight }(\mathrm{mg} / \mathrm{larva}) \\
\pm \mathrm{SE}\end{array}$ & $\begin{array}{c}\mathrm{LD}_{50}(\mathrm{mg} \text { B.t.t./larva }) \\
\times 10^{-6} \pm \mathrm{SE}\end{array}$ \\
\hline Darmstadt & $1.13 \pm 0.12 \mathrm{a}$ & $2.38 \pm 0.12 \mathrm{~b}$ \\
Michelfeld & $1.31 \pm 0.09 \mathrm{a}$ & $2.41 \pm 0.53 \mathrm{~b}$ \\
\hline
\end{tabular}

Numbers in a column followed by some letter are not significantly different $(\mathrm{P}=0.05)$ by $\mathrm{t}$-test.

Table 3

Body weight, $\mathrm{LD}_{50}$ value and slope for each population after the concentration of all replicates

\begin{tabular}{lcccc}
\hline Population & $\begin{array}{c}\text { Body weight } \\
(\mathrm{mg} / \mathrm{larva}) \pm \mathrm{SE}\end{array}$ & $\begin{array}{c}\mathrm{LD}_{50}(\mathrm{mg} \text { B.t.t./larva }) \\
\times 10^{-6}\end{array}$ & $\begin{array}{c}\mathrm{LD}_{50} \\
95 \% \text { fiducial limits }\end{array}$ & $\begin{array}{c}\text { Slope of the } \\
\text { regression line } \pm \mathrm{SE}\end{array}$ \\
\hline Darmstadt & $1.13 \pm 0.12$ & 2.38 & $2.12-2.68$ & $2.88 \pm 0.16$ \\
Michelfeld & $1.31 \pm 0.09$ & 2.12 & $1.88-2.39$ & $2.08 \pm 0.15$ \\
\hline
\end{tabular}

Table 4 shows the estimate of relative medium potency with the $95 \%$ fiducial limits. By this method the Darmstadt population is just 1.12 times more resistant than the Michelfeld population, but the fiducial limits show that there is no difference between the populations regarding the susceptibility to B.t.t. 


\section{Table 4}

Comparing the B.t.t. susceptibility of the populations (after the concentration of all replicates)

\begin{tabular}{lcc}
\hline $\begin{array}{c}\text { Comparing the } \\
\text { population }\end{array}$ & $\begin{array}{c}\text { Estimate of relative } \\
\text { medium potency }\end{array}$ & $\begin{array}{c}95 \% \text { fiducial } \\
\text { limits }\end{array}$ \\
\hline Darmstadt: Michelfeld & 1.12 & $0.95-1.33$ \\
\hline
\end{tabular}

These data do not accord with the results of Whalon et al. (1993), and Rahardja and Whalon (1995). One reason may be that the American scientists have worked under laboratory conditions; the observed resistance of CPB was due to a permanent B.t.t. treatment. Another possibility could be that the farm where the Michelfeld population was collected from, is spraying NOVODOR FC only since 1993, once or twice a year. This spraying period may be too short to develop a resistance. The third possibility is that the imagines collected from the farm in Michelfeld were flown in from another region. The probability for this is low, because the farm is relatively separated from others, situated in a valley, and the field of the next potato grower was found $3 \mathrm{~km}$ far away, but not $100 \%$ excludable.

Although, until now, in our investigations no occurrence of resistance was verified (if NOVODOR FC applied once or twice a year), to avoid the development of resistance, the growers should sometimes alternate NOVODOR FC with other insecticides. However, due to the negative experience in laboratory investigations it will be necessary to test the susceptibility of CPB after every five years in which B.t.t. was used, in order to recognize a diminished susceptibility to this pathogen. For these monitoring studies our standardized bioassay method is suitable.

\section{Literature}

Abbott, W. S. (1925): A method of computing the effectiveness of an insecticide. J. Econ. Entomol. 18, $265-267$. Daum, R. J. and Killcreas, W. (1966): Two computer programs for probit analysis. Bull. Entomol. Soc. Amer. $12,365-369$.

Ferro, D. N. and Gelernter, W. D. (1989): Toxicity of a new strain of Bacillus thuringiensis to Colorado potato beetle (Coleoptera: Chrysomelidae). J. Econ. Entomol. 82, 750-755.

Ferro, D. N. and Lyon, S. M. (1991): Colorado potato beetle (Coleoptera: Chrysomelidae) larval mortality: operative effects of Bacillus thuringiensis subsp. san diego. J. Econ. Entomol. 84, 806-809.

Finney, D. J. (1971): Probit analysis, 3rd. ed. Cambridge University Press, London.

Gasser, C. S. and Fraley, R. T. (1989): Genetically engineering plants for crop improvement. Science (Washington DC) $244,1293-1299$.

Gürlich, G. and Langenbruch, G. A. (1994): Das Verhalten des Kartoffelkäfers (Leptinotarsa decemlineata Say) und die Folgen für die biologische Bekämpfung. Mitt. Dtsch. Ges. Allg. Angew. Entomol. 9, 57-62.

Herrnstadt, C., Soares, G. G., Wilcox, E. R. and Edwards, D. L. (1986): A new strain of Bacillus thuringiensis with activity against coleopteran insects. Bio/Technology 4, 305-308. 
Hough-Goldstein, J., Tisler, A. M., Zehnder, G. W. and Uyeda, K. A. (1991): Colorado potato beetle (Coleoptera: Chrysomelidae) consumption of foliage treated with Bacillus thuringiensis var. san diego and various feeding stimulants. J. Econ. Entomol. 84, 87-93.

Krieg, A., Huger, A. M., Langenbruch, G. A. and Schnetter, W. (1983): Bacillus thuringiensis var. tenebrionis: ein neuer, gegenüber Larven von Coleopteren wirksamer Pathotyp. Z. Ang. Entomol. 96, 500-508.

Krieg, A., Huger, A. M., Langenbruch, G. A. and Schnetter, W. (1984): Neue Ergebnisse über Bacillus thuringiensis var. tenebrionis unter besonderer Berücksichtigung seiner Wirkung auf den Kartoffelkäfer (Leptinotarsa decemlineata). Anz. Schädlingskde., Pflanzenschutz, Umweltschutz 57, 145-150.

Krieg, A., Huger, A. M. and Schnetter, W. (1987): Bacillus thuringiensis var. san diego M-7 ist identisch mit dem zuvor in Deutschland isolierten käferwirksamen B. thuringiensis subsp. tenebrionis Stamm BI-256-82. J. Appl. Entomol. 104, 417-424.

Langenbruch, G. A., Krieg, A., Huger, A. M. and Schnetter, W. (1985): Erste Feldversuche zur Bekämpfung der Larven des Kartoffelkäfers (Leptinotarsa decemlineata) mit Bacillus thuringiensis var. tenebrionis. Med. Fac. Landbouww. Rijksuniv. Gent 50/2a, 441-449.

Langenbruch, G. A. and Riethmüller, U. (1990): Kartoffelkäferbekämpfung mit Bacillus thuringiensis subsp. tenebrionis. Nachrichtenbl. Deut. Phlanzenschutzd. 42, 65-69.

Langenbruch, G. A. and Hommel, B. (1991): Zur Bekämpfung des Kartoffelkäfers (Leptinotarsa decemlineata) mit Bacillus thuringiensis ssp. tenebrionis. Gesunde Pflanzen 43, 193-196.

Langenbruch, G. A. (1992): Erfahrungen bei der Bekämpfung des Kartoffelkäfers (Leptinotarsa decemlineata) mit Bacillus thuringiensis subsp. tenebrionis. Mitt. Dtsch. Ges. Allg. Angew. Ent. 8, 193-195.

Rahardja, U. and Whalon, M. E. (1995): Inheritance of resistance to Bacillus thuringiensis subsp. tenebrionis CryIIIA $\delta$-Endotoxin in Colorado potato beetle (Coleoptera: Chrysomelidae). J. Econ. Entomol. 88, 21-26.

Riethmüller, U. and Langenbruch, G. A. (1989): Zwei Biotestmethoden zur Prüfung von Bacillus thuringiensis subspec. tenebrionis gegen Larven des Kartoffelkäfers (Leptinotarsa decemlineata). Entomophaga 34, 237-245.

Trisyono, A. and Whalon, M. E. (1997): Fitness costs of resistance to Bacillus thuringiensis in Colorado potato beetle (Coleoptera: Chrysomelidae). J. Econ. Entomol. 90, 267-271.

Whalon, M. E., Miller, D. L., Hollingworth, R. M., Grafius, E. J. and Miller, J. R. (1993): Selection of a Colorado potato beetle (Coleoptera: Chrysomelidae) strain resistant to Bacillus thuringiensis. J. Econ. Entomol. 86, 226-233.

Zehnder, G. W. and Gelernter, W. D. (1989): Activity of the M-ONE formulation of a new strain of Bacillus thuringiensis against the Colorado potato beetle (Coleoptera: Chrysomelidae): relationship between susceptibility and insect life stage. J. Econ. Entomol. 82, 756-761. 